https://doi.org/10.17816/MAJ191S1184-186

\title{
HUMAN BETA-DEFENSIN-3 GENE EXPRESSION IN THE NASAL AND SINONASAL MUCOSA
}

\author{
E.V. Tyrnova \\ Saint Petersburg Research Institute of Ear, Nose, Throat and Speech, Saint Petersburg, Russia

\section{ЭКСПРЕССИЯ ГЕНА БЕТА-ДЕФЕНСИНА-З ЧЕЛОВЕКА В СЛИЗИСТОЙ ОБОЛОЧКЕ НОСА И ОКОЛОНОСОВЫХ ПАЗУХ}

\author{
Е.В. Тырнова
}

ФГБУ «Санкт-Петербургский научно-исследовательский институт уха, горла, носа и речи» МЗ РФ, Санкт-Петербург

Sensitive receptors of the olfactory sensory system are located in the nasal cavity mucosa. The aim of this study was to evaluate the human beta-defensin-3 (hBD-3) gene expression in the surface epithelium of the nasal and sinonasal mucosa. Surgical samples from patients with nasal and sinonasal disease $(n=85)($ sinus maxillaries mucosa, choana polyps, middle nasal passage polyps, sinus maxillaries polyps, inferior turbinate mucosa of hypertrophic rhinitis, inferior turbinate mucosa and the middle nasal passage mucosa as controls) were investigated. Total RNA was extracted and analysed by real-time RT-PCR for hBD-3 as well as betaactin mRNA.

hBD-3 gene expression was detected in all examined anatomical regions in 14.29-33.33\% samples at low levels, but it was absent in the hypertrophic inferior turbinate mucosa (Fisher's exact test, $p<0.05$ compared to the middle nasal passage mucosa; $p<0.01$, odds ratio (OR) 31.15 , 95\% confidence interval (CI) $1.53 \div 633.6$ compared to the middle nasal passage polyps). The highest hBD-3 mRNA expression detection frequency was detected in the middle nasal passage polyps $(53.84 \%$ cases $)(p<0.05$, OR 7.00, CI $1.10 \div 44.63$ compared to the sinus maxillaries mucosa). The highest levels of hBD-3 gene expression was detected in the middle nasal passage polyps also (Wilcoxon signed rank test, $p<0.05$ compared to the hypertrophic inferior turbinate mucosa). Clinically, inflammatory polyps are found in the middle turbinate in patients with chronic rhinosinusitis but not in the inferior turbinate. In the context of chronic inflammation, apart from direct antimicrobial activity, high concentrations hBD-3 also potentially contributes to epithelial injury and fibrotic remodeling.

Keywords: human beta-defensin-3 (hBD-3); nasal and sinonasal mucosa; chronic rhinosinusitis; nasal polyp; gene expression.

Чувствительные рецепторы сенсорной обонятельной системы локализованы в слизистой оболочке полости носа. Цель работы: оценить экспрессию гена бета-дефенсина-3 (hBD-3) в поверхностном эпителии слизистой оболочки носа и околоносовых пазух. Исследован операционный материал больных заболеваниями носа и околоносовых пазух $(n=85)$ (слизистая оболочка верхнечелюстных пазух, хоанальные полипы, полипы среднего носового хода, полипы верхнечелюстных пазух, нижние носовые раковины при гипертрофическом рините, нижние носовые раковины и слизистая оболочка среднего носового хода в качестве контроля). Оценку экспрессии мРHK hBD-3, а также бета-актина проводили методом обратной транскрипции и полимеразной цепной реакции в режиме реального времени. Экспрессия гена hBD-3 детектирована на низких уровнях в 14,29-33,33 \% образцов, отсутствовала в гипертрофических нижних носовых раковинах (точный тест Фишера, $p<0,05$ по сравнению со слизистой среднего носового хода; $p<0,01$, отношение шансов (ОШ) 31,15 , доверительный интервал (ДИ) $1,53 \div 633,6$ по сравнению с полипами среднего носового хода). Самая высокая частота детекции экспрессии мРНK hBD-3 в полипах среднего носового хода $(53,84 \%$ случаев) $(p<0,05$, ОШ 7,00, ДИ 1,10 44,63 по сравнению со слизистой оболочкой верхнечелюстных пазух). Наиболее высокие уровни экспрессии гена hBD-3 также в полипах среднего носового хода (знаковый тест Вилкоксона $p<0,05$ по сравнению с гипертрофическими нижними носовыми раковинами). Клинически воспалительные полипы обычно находятся в средних носовых раковинах больных хроническим риносинуситом, а не в нижних носовых раковинах. В контексте хронического воспаления, помимо прямой микробоцидной активности hBD-3 на первой линии защиты, высокие концентрации hBD-3 потенциально способствуют повреждению эпителия и фиброзному ремоделированию.

Ключевые слова: бета-дефенсин-3 человека (hBD-3); слизистая оболочка носа и околоносовых пазух; хронический риносинусит; носовые полипы; экспрессия гена.

The immune system's ability to recognize and communicate information to the nervous system about the presence of viruses and bacteria has earned it a label as the so-called sixth sense [3].
Sensitive receptors of the olfactory sensory system are located in the nasal cavity mucosa. The first line of the respiratory tract defense is represented by the airway epithelium, a pseudostratified epi- 
Detection frequency of hBD-3 gene expression in the nasal and sinonasal mucosa

\begin{tabular}{|c|c|c|c|c|c|c|}
\hline \multirow{2}{*}{$\begin{array}{l}\mathrm{N} \\
\text { groups }\end{array}$} & \multirow{2}{*}{ Surgical mucosal samples } & \multicolumn{3}{|c|}{ Patients characteristics } & \multicolumn{2}{|c|}{$\begin{array}{l}\text { hBD- } 3 \text { gene expression } \\
\text { frequency detection }\end{array}$} \\
\hline & & $\begin{array}{c}\text { Sex } \\
\text { male/female }\end{array}$ & $\begin{array}{c}\text { Age } \\
\text { (years) }\end{array}$ & Diagnosis & Abs. $n$. & $\%$ \\
\hline 1 & $\begin{array}{l}\text { Middle nasal passage } \\
\text { mucosa (control } 1 \\
\text { without mucosal disease) }\end{array}$ & $5 \mathrm{~m} / 8 \mathrm{f}$ & $19-64$ & $\begin{array}{l}\text { frontal sinus cyst / sphenoiditis / } \\
\text { maxillary sinus cyst / septal } \\
\text { deviation / epiphora / liquorrhea } \\
\text { nasalis / dacryocystitis/ maxillary } \\
\text { sinus foreign body }\end{array}$ & $4 / 13$ & 30.77 \\
\hline 2 & $\begin{array}{l}\text { Inferior turbinate mucosa } \\
\text { (control } 2 \text { without } \\
\text { mucosal disease) }\end{array}$ & $9 \mathrm{~m} / 4 \mathrm{f}$ & $19-57$ & septal deviation & $2 / 13$ & 15.38 \\
\hline 3 & $\begin{array}{l}\text { Hypertrophic inferior } \\
\text { turbinate mucosa }\end{array}$ & $7 \mathrm{~m} / 6 \mathrm{f}$ & $15-60$ & $\begin{array}{l}\text { septal deviation and hypertrophic } \\
\text { rhinitis }\end{array}$ & $0 / 13$ & 0 \\
\hline 4 & Maxillary sinus mucosa & $6 \mathrm{~m} / 8 \mathrm{f}$ & $17-53$ & $\begin{array}{l}\text { foreign body / cystiform } \\
\text { formation of maxillary sinus }\end{array}$ & $2 / 14$ & 14.29 \\
\hline 5 & $\begin{array}{l}\text { Nasal choana polyp } \\
\text { mucosa }\end{array}$ & $9 \mathrm{~m} / 4 \mathrm{f}$ & $13-58$ & chronic polyposis rhinosinusitis & $2 / 13$ & 15.38 \\
\hline 6 & $\begin{array}{l}\text { Maxillary sinus polyp } \\
\text { mucosa }\end{array}$ & $6 \mathrm{~m} / 0 \mathrm{f}$ & $13-46$ & & $2 / 6$ & 33.33 \\
\hline 7 & $\begin{array}{l}\text { Middle nasal passage and } \\
\text { ethmoidal polyps mucosa }\end{array}$ & $9 m / 4 f$ & $36-76$ & & $7 / 13$ & 53.84 \\
\hline
\end{tabular}

thelium of basal cells, ciliated cells, and goblet cells [5]. The epithelial cell layer contributes greatly to nasal and sinonasal innate immunity through physical barrier function, mucociliary clearance, and secretion of antimicrobial products.

The aim of this study was to evaluate the human beta-defensin-3 (hBD-3) gene expression in the surface epithelium of the nasal and sinonasal mucosa.

Material and methods. Mucosal samples were obtained from 85 adult patients with nasal and sinonasal disease undergoing nasal septum operation, functional endoscopic sinus surgery and inferior turbinate reduction under general anaesthesia, and classified according to the clinical diagnoses and the anatomical regions. Seven groups were defined; healthy tissue of the middle nasal passage mucosa and normal inferior turbinate mucosa that served as controls (table 1).

Mucosal biopsy specimens were taken intraoperatively from the nasal or sinonasal cavity. The mucosal tissues were preserved immediately in $0.2 \mathrm{~mL}$ of RNAlater (Ambion). The tissue samples were stored in RNAlater at $-20{ }^{\circ} \mathrm{C}$ until they were processed for RNA isolation. Mucosal samples were thoroughly grinded with a mortar and pestle and homogenized using Pellet Pestle Motor (Kontes) (Sigma-Aldrich). Total RNA was extracted from the superficial epithelium of mucosa using the Gen Elute Mammalian Total RNA Miniprep Kit (RTN70) and On-Column DNase I Digestion Set (DNASE70) according to the manufacturer's instructions (Sigma-Aldrich). Total RNA of $2 \mathrm{mg}$ was reverse transcribed to generate cDNA with M-MLV RT (Promega) in the presence of oligo(dT), RNasin ${ }^{\circledR}$ and dNTPs (Medigen). Real-time polymerase chain reaction (RT-PCR) was performed using $\mathrm{iQ}^{\mathrm{TM}}$ SYBR Green Supermix (Bio-Rad) and specific primers (sense 5'-tatcttctgtttgctttgctcttcc-3' and antisense $5^{\prime}$-cctctgactctgcaataatatttctgtaat-3') [1], and measured with CFX-96 Touch ${ }^{\mathrm{TM}}$ and software CFX Manager $^{\mathrm{TM}}$ version 2.1 (Bio-Rad). Reactions were incubated for $5 \mathrm{~min}$ at $95^{\circ} \mathrm{C}$, followed by 40 cycles of a two-step amplification-procedure composed of annealing/extension at $60^{\circ} \mathrm{C}$ for $1 \mathrm{~min}$ and denaturation for $10 \mathrm{~s}$ at $95^{\circ} \mathrm{C}$. Plate read was performed at $72{ }^{\circ} \mathrm{C}$. Specificity reaction products were evaluated by melt curve. Melt temperature of the amplification products was $78^{\circ} \mathrm{C}$ for hBD-3 and $88^{\circ} \mathrm{C}$ for beta-actin. The relative hBD-3 mRNA expression of the samples was standardized using software with beta-actin mRNA as a housekeeping control (sense 5'-gggtcagaaggattcctatg-3', antisense 5'-ggtctcaaacatgatctggg-3').

Statistical analysis was performed using GraphPad Prism 5 software. Distribution of the samples was tested with the Kolmogorov-Smirnov test. Comparison of numerical data between groups was first established using the Kruskal-Wallis test, then the Wilcoxon signed rank test. Comparison of proportions between groups was carried out using Fisher's exact test and odds ratio (OR). P-values less than 0.05 were considered statistically significant. 
Results and discussion. The expression of hBD-3 gene was detected in all defined anatomical regions at low levels, but it was absent in the hypertrophic inferior turbinate mucosa $(p<0.05$ compared to the middle nasal passage mucosa; $p<0.01$, OR $31.15,95 \%$ confidence interval (CI) $1.53 \div 633.6$ compared to the middle nasal passage polyps) (table 1). The highest detection frequency of hBD-3 mRNA expression was detected in the middle nasal passage polyps $(p<0.05$, OR 7.00 , CI $1.10 \div 44.63$ compared to the sinus maxillaries mucosa). The highest levels of hBD-3 gene expression was detected in the middle nasal passage polyps also $(p<0.05$ compared to the hypertrophic inferior turbinate mucosa).

The epithelial cells of the nose and paranasal sinuses must maintain an adequate mucosal defense system against invading pathogens and various antigenic stimuli. The innate immune response provides protection immediately after an infectious challenge. The nasal and sinonasal epithelium contains a chemical defense shield through the expression and secretion of various antimicrobial peptides [4]. Protecting the upper airway from microbial infection is an important function of the immune system [3]. Clinically, inflammatory polyps are found in the middle turbinate in patients with chronic rhinosinusitis but not in the inferior turbinate [6]. Excessive activity of the immune system can cause self-damage of the host by immunopathological processes [5]. hBD-3-stimulated TLR1/2 activation induces a pro- rather than an anti-inflammatory cytokine pattern in monocytes [2].

Conclusions. Our findings suggested that epithelial in the nasal and sinonasal mucosa were a physical barrier, which could represent a defense mechanism without severe inflammation. Expression of hBD-3 in proximity to areas of cellular dysregulation may inadvertently exacerbate disease progression. In the context of chronic inflammation, apart from direct antimicrobial activity, high concentrations hBD-3 also potentially contributes to epithelial injury and fibrotic remodeling.

\section{References}

1. Тырнова Е.В., Алешина Г.М., Янов Ю.К., Кокряков В.Н. Изучение экспрессии гена бетадефенсина-3 человека в слизистой оболочке верхних дыхательных путей // Рос. оториноларингол. 2015. - № 2 (75). - C. 77-84.

2. Funderburg NT, Jadlowsky JK, Lederman MM, et al. The toll-like receptor $1 / 2$ agonists Pam(3) CSK(4) and human $\beta$-defensin-3 differentially induce interleukin-10 and nuclear factor- $\kappa B$ signalling patterns in human monocytes. Immunology. 2011;134:151-160. https://doi.org/10.1111/j.1365-2567.2011.03475.x.

3. Hariri BM, Cohen NA. New insights into upper airway innate immunity. Am. J. Rhinol. Allergy. 2016;3:319-323. https://doi.org/10.2500/ajra.2016.30.4360.

4. Laudien M, Dressel S, Harder J, Gläser R. Differential expression pattern of antimicrobial peptides in nasal mucosa and secretion. Rhinology. 2011;49(1):107-111. https://doi.org/10.4193/Rhino10.036.

5. Seiler F, Bals R, Beisswenger C. Function of Antimicrobial Peptides in Lung Innate Immunity. In: Antimicrobial Peptides. Birkhäuser Advances in Infectious Diseases. Ed. by J. Harder, J.M. Schröder. Springer, Cham; 2016. P. 33-52.

6. White LC, Weinberger $\mathrm{P}$, Coulson $\mathrm{H}$, et al. Why sinonasal disease spares the inferior turbinate: An immunohistochemical analysis. Laryngoscope. 2016;126(5):E179-183. https://doi.org/10.1002/lary.25791. 